\title{
RANCANG BANGUN APLIKASI PERMAINAN ADVENTURE OF FRUNIMAL UNTUK EDUKASI BAHASA INGGRIS BERBASIS ANDROID
}

\author{
Muhammad Ridwan \\ Fakultas Teknik dan Ilmu Komputer, Program Studi S1 Informatika \\ Universitas Teknokrat Indonesia \\ Email: muh.ridwan444@gmail.com \\ Purwono Prasetyawan \\ Fakultas Teknik dan Ilmu Komputer, Program Studi S1 Sistem Informasi \\ Universitas Teknokrat Indonesia \\ Email: purwono.prasetyawan@teknokrat.ac.id
}

\begin{abstract}
ABSTRAK
Penelitian ini bertujuan untuk membangun sebuah aplikasi permainan berjenis platformer game yang menghibur dengan tema buah dan hewan dalam bahasa inggris, dan untuk mengetahui kualitas aplikasi permainan tersebut menggunakan standar ISO 25010 dari aspek functional suitability, performance efficiency, compatibility, dan usability. Metode pengembangan aplikasi ini menggunakan MDLC (Multimedia Development Life Cycle). Hasil dari penelitian dapat diketahui bahwa game edukasi bahasa Inggris “Adventure of Frunimal” berhasil dikembangkan dengan game engine Construct2 dengan metode pengembangan Multimedia Luther. Pengujian pada aspek functional suitability sudah memenuhi standar AQuA, pada aspek performance efficiency sudah memenuhi ambang batas aman yang ditetapkan oleh Little Eye dan tidak terjadi memory leak, pada aspek compatibilitydapat berjalan pada OS Android dari versi Ice Cream Sandwich sampai Marshmallow, dan pada aspek usability secara keseluruhan didapatkan hasil baik dalam hal kegunaan, mudah digunakan dan dipelajari serta memuaskan.
\end{abstract}

Kata kunci: game edukasi, bahasa inggris, media pembelajaran, android.

\begin{abstract}
The aim of this research is to build an entertaining game game with game theme and animal theme in English, and to know the quality of game application using ISO 25010 standard from functional suitability aspect, performance efficiency, compatibility, and usability. The applicaton development method using MDLC. The results of the research can be seen that the English educational game "Adventure of Frunimal" successfully developed with game engine Construct 2 with Multimedia Luther development method. Tests on the aspect of functional suitability already meet the AQuA standard, on the aspect of performance efficiency already meets the safe threshold set by Little Eye and no memory leak, on compatibility aspect can run on Android OS from Ice Cream Sandwich to Marshmallow, and on usability aspect overall good results in terms of usability, easy to use and learned and satisfactory.
\end{abstract}

Keywords: game education, english, learning media, android.

\section{PENDAHULUAN}

Bahasa merupakan sarana dalam berkomunikasi. Bahasa yang dipakai sebagai bahasa internasional saat ini adalah bahasa Inggris. Bahasa Inggris juga termasuk kedalam pelajaran wajib di sekolah termasuk di Indonesia. Pada anak-anak usia sekolah dasar antara 6-9 tahun tentunya diajarkan tentang bahasa Inggris yang sifatnya dasar juga, termasuk tema materi pengenalan objek yang ada disekitarnya. Namun, pada umumnya anak-anak masih mengalami kesulitan mempelajari bahasa Inggris karena dirasa terlalu sulit dan kurang menyenangkan. Sehingga anak-anak kurang termotivasi dalam belajar bahasa Inggris. Oleh karena itu diperlukan media pembelajaran yang menyenangkan dan menarik. Pemilihan suatu media pembelajaran bertujuan untuk mempermudah pelaksanaan kegiatan pembelajaran, sehingga tujuan pembelajaran dapat tercapai dengan hasil yang baik dan maksimal.

Permainan (game) adalah sebuah sistem dimana pemain terlibat dalam konflik buatan, ditentukan oleh aturan yang menghasilkan hasil yang terukur. Game juga bisa dikatakan sesuatu yang memiliki akhir dan cara pencapaiannya [1]. Dalam game terdapat tujuan, hasil dan serangkaian peraturan untuk mencapai 
keduanya. Sehingga dapat disimpulkan game merupakan sebuah sistem dimana pemain terlibat dalam konflik buatan yang sudah ditentukan oleh aturan untuk menghasilkan suatu tujuan tertentu.

Permainan pendidikan (education game) adalah permainan yang dirancang dengan tujuan khusus untuk mengajarkan pengguna tentang sesuatu hal. Dapat mengembangkan konsep, pemahaman dan membimbing serta melatih kemampuan pengguna. Selain itu permainan ini juga harus bisa memberikan motivasi kepada pengguna untuk terus memainkannya[2].

Manfaat game edukasi secara umum antara lain membuat anak lebih termotivasi karena game edukasi merupakan metode pembelajaran yang menarik dan interaktif. Proses belajar dapat dilakukan dimana saja dan kapan saja. Game dapat menyediakan cara yang inovatif dalam pembelajaran [3], antara lain:

a) Game dapat memberikan unsur interaktivitas yang dapat merangsang pembelajaran.

b) Game memungkinkan peserta untuk mendapatkan hal yang baru, meningkatkan rasa ingin tahu, dan tantangan yang dapat merangsang dalam pembelajaran.

c) Game dapat membekali anak-anak dengan pengetahuan tentang teknologi.

d) Game dapat membantu untuk pengembangan skill di bidang IT.

e) Game dapat digunakan sebagai simulasi dan dapat memberikan hiburan.

Android merupakan sistem operasi yang digunakan dalam perangkat mobile. Menurut data yang dirilis oleh netmarketshare.com pada periode Oktober 2015 sampai Agustus 2016, android masih menjadi yang teratas dalam penggunaan sistem operasi pada perangkat mobile secara global. Pada periode terakhir bulan Agustus 2016 saja, presentase pengguna android sudah mencapai angka 66, 87\% jauh diatas pesaingya yaitu iOS yang hanya mencapai $27,20 \%$.

\section{METODOLOGI PENELITIAN}

Ada beberapa metode yang dilakukan dalam penelitian ini, yaitu metode pengembangan multimedia Luther, dan metode pengujian perangkat lunak ISO 25010.Tahapan pengembangan Multimedia Development Life CycleLuther terdiri dari enam tahap, yaitu concept, design, obtainingmaterial collecting, assembly, testing, dan distribution [4].

\subsection{Concept (Konsep)}

Pada penelitian ini akan dikembangkan sebuah game dengan konsep edukasi bahasa Inggris berupa petualangan berjenis platformer game dengan tampilan interface 2 dimensi yang menghibur dengan tema buah-buahan dan hewan yang mempunyai dua jenis pertanyaan yaitu memasangkan gambar dengan jawaban yang sesuai dan penyusunan huruf acak menjadi satu kata yang sesuai dengan gambar. Berikut adalah deskripsi dari konsep game, dapat dilihat pada tabel 1.

Tabel 1. Deskripsi konsep game

\begin{tabular}{lll}
\hline Judul & $:$ & Adventure of Frunimal \\
\hline Genre & $:$ & Platformer \\
Platform & $:$ & Android \\
Target Audiens & $:$ & Anak-anak 6-9 tahun \\
Stages & $:$ & 4 Stages \\
Level & $:$ & 4 Level/Stage \\
Pemain & $:$ & 1 Pemain \\
Musuh & $:$ & 10 Musuh / Level 1 \\
& & 20 Musuh / Level 2 \\
& & 30 Musuh / Level 3 \\
& & 40 Musuh / Level 4 \\
\hline
\end{tabular}

\subsection{Design (Perancangan)}

Dalam tahapan design (perancangan) ini membuat storyboard, struktur navigasi dan flowchart. Menurut Vaughan dalam Sutopo[4], menyatakan bahwa struktur navigasi terdapat empat macam antara lain linear, hierarchical, nonlinear, dan composite.

Struktur navigasi merupakan hubungan antar menu. Struktur navigasi juga dapat mempermudah dalam mendeskripsikan rancangan navigasi pada game ini. Struktur navigasi pada game ini menggunakan model hierarchical. Adapun gambaran struktur navigasi dapat dilihat pada Gambar 1. 


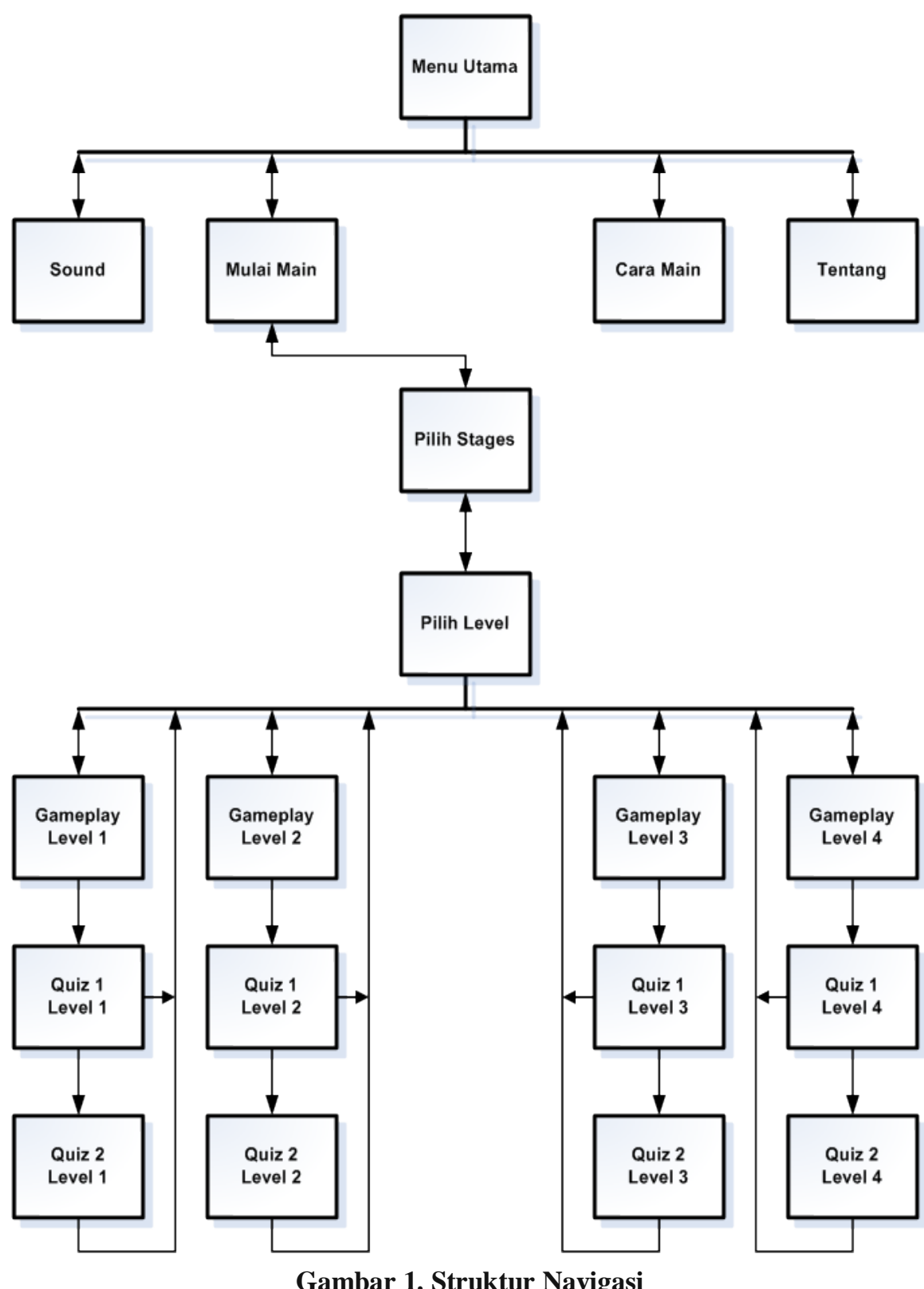

Gambar 1. Struktur Navigasi

\subsection{Obtaining Content Material (Pengumpulan Bahan)}

Dalam tahap ini dilakukan pengumpulan berupa gambar-gambar seperti karakter, background dan objek beserta suara-suara yang akan dipakai pada game. Pada penelitian ini material yang digunakan bersumber dari beberapa web penyedia material secara gratis. Dalam tahap ini dapat dilakukan bersamaan dengan tahap assembly.

\subsection{Assembly (Pembuatan)}

Pada tahap ini, perancangan yang sudah dilakukan kemudian diimplementasikan menjadi game secara utuh. Pengkodean pada game ini menggunakan Construct 2 sebagai game engine. Construct 2 menggunakan HTML 5 sebagai bahasa pemrogramannya. Pengkodean pada Construct 2 dilakukan dengan cara pemberian action kondisi pada event sheet di masing-masing layout. Berikut ini adalah tampilan utama game bisa dilihat pada Gambar 2. 


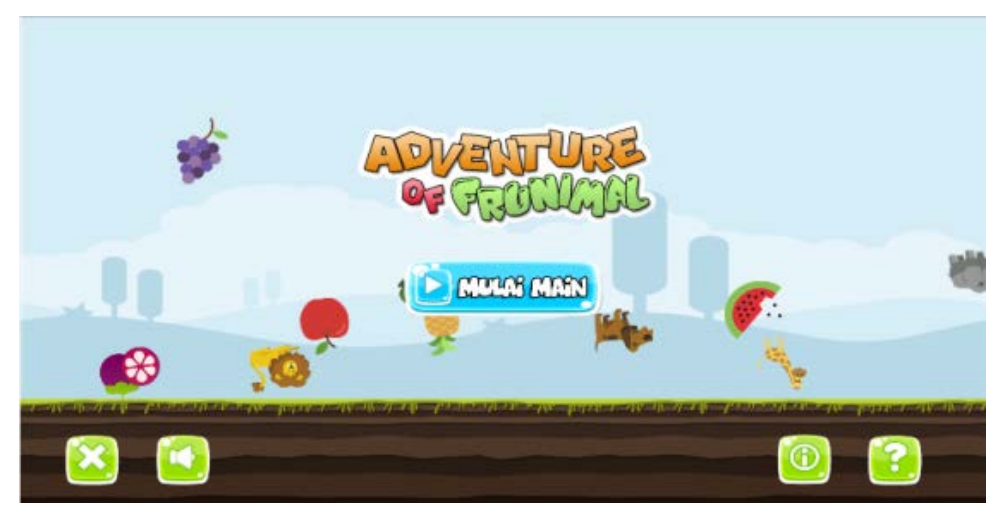

Gambar 2. Tampilan Menu Utama

\subsection{Testing (Pengujian)}

Setelah tahapan assembly selesai, maka selanjutnya akan dilakukan pengujian. Pengujian kualitas perangkat lunak dilakukan sesuai dengan standar ISO 25010. Berikut ini merupakan teknik analisis data yang digunakan dalam beberapa pengujan yang dilakukan.

a) Aspek Functional Suitability

Pengujian aspek ini menggunakan test case dengan skala pengukuran Gutmann dengan alternatif jawaban sukses dan gagal. Setelah hasil pengujian didapat kemudian dibandingkan dengan kriteria yang terdapat pada dokumen Testing Criteria for Android Application yang dikembangkan oleh AQuA.Kriteria yang digunakan adalah kriteria functionality sanity check. Kriteria tersebut dapat dilihat pada tabel 2.

Tabel 2. Standar aspek kualitas functional suitability

\begin{tabular}{l} 
Kriteria Lolos \\
\hline Semua fungsi utama aplikasi seperti algoritma, perhitungan, \\
pengukuran, pembagian skor, dan lain sebagainya harus berjalan \\
dengan benar.
\end{tabular}

b) Aspek Performance Efficiency

Analisis aspek performance efficiency dapat diambil dari penggunaan memori dan CPU dengan menggunakan alat analisis Tesdroid. Kriteria dalam pengujian performance efficiency adalah penggunaan memori yang tidak sampai menyebabkan memory leak dan penggunaan CPU tidak menyentuh batas aman yang ditentukan oleh Little Eye yaitu sebesar 15\%. Pengujian dikatakan memenuhi aspek performance efficiency jika memenuhi kriteria tersebut.

c) Aspek Compatibility

Pada pengujian compability dilakukan dengan cara mencoba aplikasi pada 5 perangkat smartphone yang berbeda-beda dari minimal sistem operasi versi Ice Cream Sandwich sampai versi Marshmallow. Pengujian ini menggunakan angket dengan skala Guttman yang memiliki dua alternatif jawaban yaitu sukses dan gagal. Setelah pengujian dilakukan data yang didapatkan akan dikonversi kedalam skala persentase untuk mengetahui tingkat kualitas aspek compatibility. Kemudian hasil pengujian dicocokan dengan tingkat kelayakan, dianalisis menggunakan analisis deskriptif dan dapat disimpulkan bahwa aplikasi telah memenuhi aspek compatibility atau tidak. Perhitungan dilakukan dengan rumus sebagai berikut:

Persentase $(\%)=\frac{\text { Nilaiyang diperoleh }}{\text { Nillai maksimal }} \times 100 \%$

Data yang didapatkan kemudian dikonversi berdasarkan tabel 3 kriteria interpretasi skor yang dikemukakan oleh Riduwan dalam Arista [5]. 
Tabel 3. Tabel interpretasi skor

\begin{tabular}{cc}
\hline Angka (\%) & Klasifikasi \\
\hline $0-20$ & Sangat Tidak Baik \\
$21-40$ & Tidak Baik \\
$41-60$ & Cukup \\
$61-80$ & Baik \\
$81-100$ & Sangat Baik \\
\hline
\end{tabular}

d) Aspek Usability

Pada pengujian aspek usability, teknik analisis data dilakukan dengan memberikan penilaian terhadap setiap jawaban responden pada kuesioner USE dengan menggunakan interval skala likert yang dikemukakan Riduwan dalam Arista[5] seperti yang disajikan pada tabel 4.

Tabel 4. Tabel interval skala likert

\begin{tabular}{cc}
\hline Alternatif Jawaban & Nilai \\
\hline Sangat Tidak Setuju & 1 \\
Tidak Setuju & 2 \\
Ragu-Ragu & 3 \\
Setuju & 4 \\
Sangat Setuju & 5 \\
\hline
\end{tabular}

Setelah diberikan penilaian kemudian dilakukan penghitungan persentase sebagai berikut:

Persentase $(\%)=\frac{\text { Nilai total }}{\text { Nilai maksimal }} \times 100 \%$

Data yang didapatkan kemudian dikonversi berdasarkan tabel 5 kriteria interpretasi skor yang dikemukakan oleh Riduwan dalam Arista [5].

Tabel 5. Tabel interpretasi skor

\begin{tabular}{cc}
\hline Angka (\%) & Klasifikasi \\
\hline $0-20$ & Sangat Tidak Baik \\
$21-40$ & Tidak Baik \\
$41-60$ & Cukup \\
$61-80$ & Baik \\
$81-100$ & Sangat Baik \\
\hline
\end{tabular}

\section{HASIL DAN PEMBAHASAN}

\subsection{Pengujian Functional Suitability}

Berdasarkan hasil yang didapatkan dari pengujian fungsional, didapatkan hasil persentase sebagai berikut:

$$
\text { Sukses } \quad=\frac{30}{30} \times 100 \%=100 \% \quad \text { Gagal }=\frac{0}{0} \times 100 \%=0 \%
$$

Berdasarkan hasil pengujian aspek functional suitability memiliki hasil persentase sukses sebesar 100\%. Maka dapat diambil kesimpulan bahwa hasil pengujian functional suitability telah sesuai dengan kriteria functional sanity check yang dikembangkan oleh AQuA (App Quality Alliance).

\subsection{Pengujian Performance Efficiency}

Pada pengujian performance efficiency, aspek yang diamati yaitu penggunaan CPU dan memory. Tools yang digunakan untuk pengujian performance efficiency yaitu Testdroid dengan dijalankan pada device LG Google Nexus versi android 6.0. 


\subsubsection{CPU}

Dari hasil pengujian performance efficiency dengan menggunakan Testdroid dalam aspek penggunaan CPU yang disajikan dalam bentuk grafik pada gambar 3 dapat dilihat penggunaan CPU berada di sumbu y sedangkan waktu ada di sumbu $\mathrm{x}$.

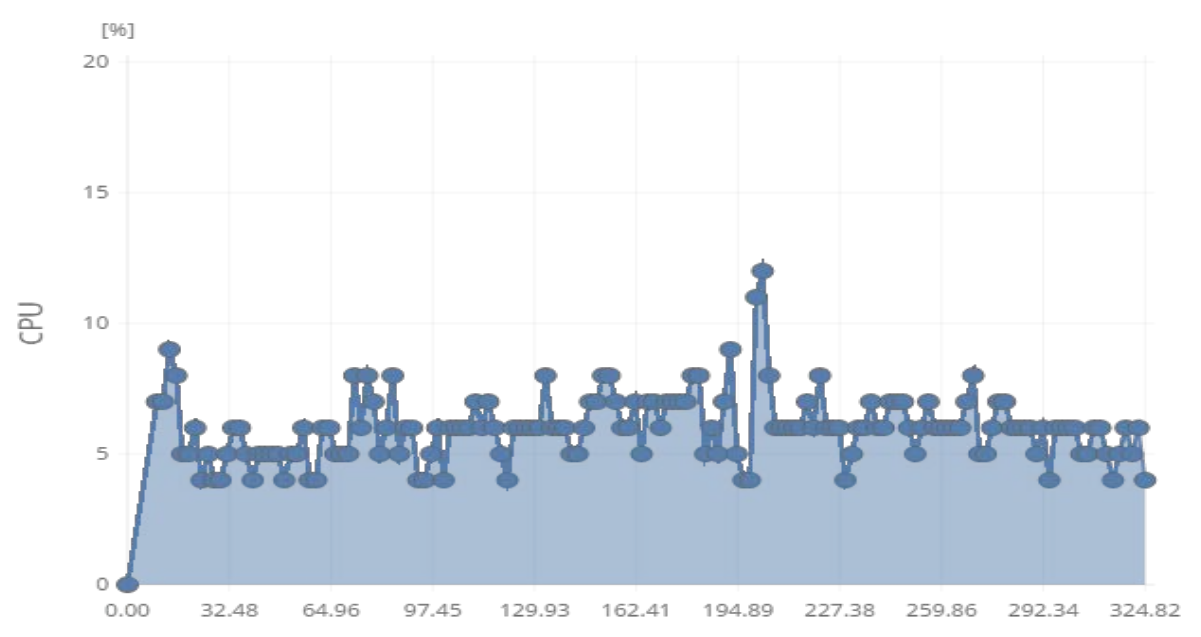

Gambar 3. Pengujian Performance Efficiency Penggunaan CPU

Berdasarkan pengujian performance efficiency yang dilakukan, penggunaan CPU paling tinggi terdapat pada periode waktu detik ke-201 hingga detik ke-203. Penggunaan CPU pada periode ini mencapai 12\%. Untuk rata-rata penggunaan CPU berada pada kisaran 6\%. Penggunaan CPU pada game yang ditampilkan pada gambar 3, jika dimasukkan dalam tabel, maka didapatkan hasil yang disajikan pada tabel 6.

Tabel 6. Penggunaan CPU pada game per 32 detik

\begin{tabular}{ccc}
\hline No. & Detik $\boldsymbol{k e}$ - & Penggunaan CPU \\
\hline 1 & 32 & $5 \%$ \\
2 & 64 & $6 \%$ \\
3 & 96 & $5 \%$ \\
4 & 128 & $6 \%$ \\
5 & 160 & $6 \%$ \\
6 & 192 & $9 \%$ \\
7 & 224 & $6 \%$ \\
8 & 256 & $7 \%$ \\
9 & 288 & $6 \%$ \\
10 & 320 & $5 \%$ \\
& Total & $\mathbf{6 1 \%}$ \\
& Rata-rata & $\mathbf{6 \%}$ \\
\hline
\end{tabular}

Berdasarkan pengujian performance efficiency menggunakan Testdroid terhadap penggunaan CPU mendapatkan hasil rata-rata penggunaan CPU per 32 detik sebesar 6\%. Jika dibandingkan dengan batas aman yang digunakan oleh Little Eye yaitu sebesar 15\%, angka tersebut masih berada dibawah batas.

\subsubsection{Memory}

Dari hasil pengujian performance efficiency dengan menggunakan Testdroid dalam aspek penggunaan memory yang disajikan dalam bentuk grafik pada gambar 4 dapat dilihat penggunaan memory berada di sumbu y sedangkan waktu ada di sumbu $\mathrm{x}$. 


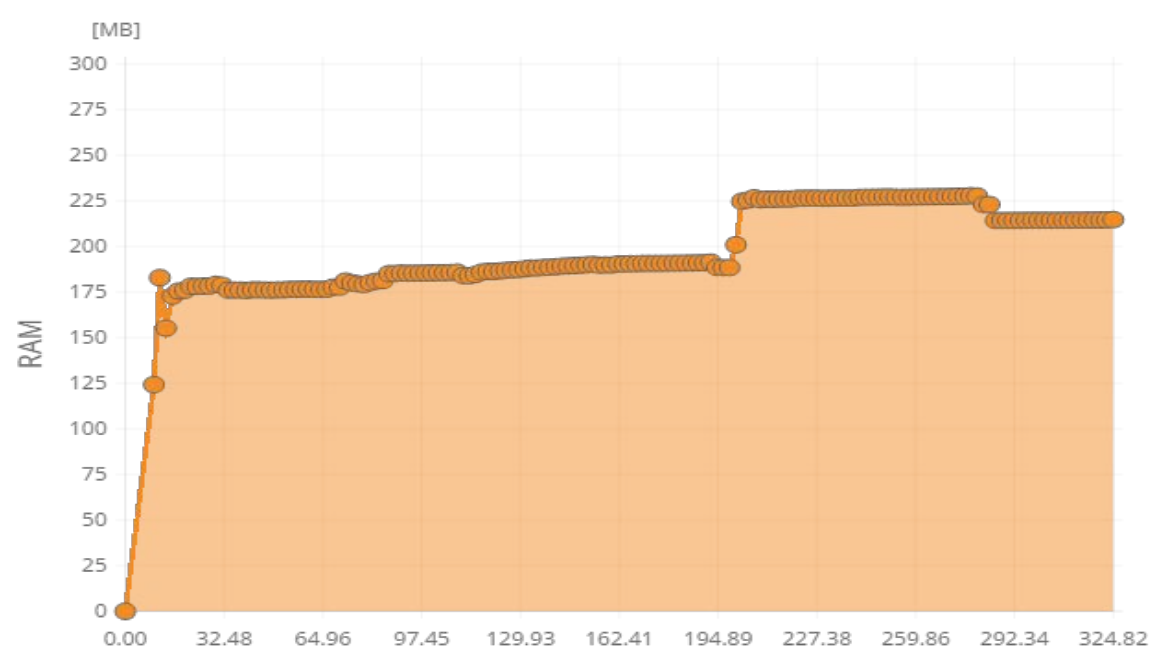

\section{Gambar 4. Pengujian Performance Efficiency Penggunaan Memory}

Berdasarkan pengujian performance efficiency yang dilakukan, pengunaan memory pada waktu dari detik ke- 0 sampai detik ke- 11 mengalami kenaikan yang sangat signifikan. Pada waktu detik ke- 11 keatas pengunaan memory sudah mulai stabil dan kembali mengalami perubahan yang signifikan pada detik ke- 203. Penggunaan memory pada game yang ditampilkan pada gambar 4, jika dimasukkan dalam tabel, maka didapatkan hasil yang disajikan pada tabel 7 .

Tabel 7. Penggunaan memory pada game per 32 detik

\begin{tabular}{ccc}
\hline No. & Detik $\boldsymbol{k e}$ - & Penggunaan Memory \\
\hline 1 & 32 & $179 \mathrm{MB}$ \\
2 & 64 & $176 \mathrm{MB}$ \\
3 & 96 & $185 \mathrm{MB}$ \\
4 & 128 & $187 \mathrm{MB}$ \\
5 & 160 & $190 \mathrm{MB}$ \\
6 & 192 & $192 \mathrm{MB}$ \\
7 & 224 & $226 \mathrm{MB}$ \\
8 & 256 & $227 \mathrm{MB}$ \\
9 & 288 & $214 \mathrm{MB}$ \\
10 & 320 & $214 \mathrm{MB}$ \\
& Total & $\mathbf{1 9 9 0} \mathbf{M B}$ \\
& Rata-rata & $\mathbf{1 9 9} \mathbf{M B}$ \\
\hline
\end{tabular}

Berdasarkan pengujian performance efficiency menggunakan Testdroid terhadap penggunaan memory mendapatkan hasil rata-rata penggunaan memory per 32 detik sebesar 199 MB. Meskipun mengkonsumsi banyak memori, game tidak menyebabkan memoryleak yang berakibat berhentinya game (force close). Hal ini bisa dilihat pada gambar 4 bahwasanya memory leak dapat dilihat dengan adanya penggunaan memori yang tiba-tiba berhenti (grafik penggunaan mengalami penurunan secara drastis). Namun pada pengujian performance efficiency, memory leak tidak terjadi.

Berdasarkan hasil yang diperoleh dari pengujian aspek performance efficiency yang dilihat dari CPU dan memori, dapat disimpulkan bahwa game Adventure of Frunimal telah memenuhi aspek performance efficiency karena konsumsi CPU masih dibawah ambang batas yang ditetapkan oleh Little Eye yaitu sebesar $15 \%$, sedangkan untuk penggunaan memori walaupun konsumsinya cukup besar namun tidak sampai menyebabkan memory leak.

\subsection{Pengujian Compatibility}

Pengujian compatibility dilakukan oleh peneliti dengan cara installasi dibeberapa device Android keluaran terakhir, mulai dari versi Ice Cream Sandwich hingga Marshmallow. Berikut hasil dari pengujian compatibility yang disajikan pada tabel 8 . 
Tabel 8. Hasil pengujian compatibility

\begin{tabular}{ccccc}
\hline No & Device & Versi Os & Proses Installasi & Proses Jalanya Aplikasi \\
\hline 1 & Smartfren Andromax I & 4.0 & Installasi berhasil & Berjalan baik \\
2 & Evercoss A28 & 4.3 & Installasi berhasil & Berjalan baik \\
3 & Xiaomi Redmi 2 & 4.4 & Installasi berhasil & Berjalan baik \\
4 & Lenovo A6010 & 5.0 & Installasi berhasil & Berjalan baik \\
5 & Himax M1 & 6.0 & Installasi berhasil & Berjalan baik \\
\hline
\end{tabular}

Berdasarkan hasil yang didapatkan dari pengujian compatibility pada tabel 8, didapatkan hasil penilaian yang disajikan pada tabel 9 sebagai berikut:

Tabel 9. Penilaian uji aspek compatibility

\begin{tabular}{clccc}
\hline No. & \multicolumn{1}{c}{ Pengujian } & Nilai & Sukses & Gagal \\
\hline 1 & Installasi pada perangkat & 5 & 5 & 0 \\
2 & $\begin{array}{l}\text { Menjalankan aplikasi pada } \\
\text { perangkat }\end{array}$ & 5 & 5 & 0 \\
$\quad$ Total & $\mathbf{1 0}$ & $\mathbf{1 0}$ & $\mathbf{0}$ \\
\hline
\end{tabular}

Dari tabel 9 kemudian dilakukan perhitungan persentase sebagai berikut:

$$
\begin{aligned}
\text { Persentase } & =\frac{\text { Nilai yang diperoleh }}{\text { Nilai maksimal }} \times 100 \% \\
& =\frac{10}{10} \times 100 \% \\
& =100 \%
\end{aligned}
$$

Berdasarkan hasil pengujian aspek compatibility dengan melakukan installasi pada device dengan versi sistem operasi seperti dalam tabel 9 memiliki hasil persentase sukses sebesar $100 \%$ dan masuk klasifikasi sangat baik. Oleh karena itu, game edukasi “Adventure of Frunimal” telah memenuhi aspek compatibility.

\subsection{Pengujian Usability}

Pengujian usability dilakukan dengan cara menggunakan kuesioner USE yang terdiri dari 30 pertanyaan dan menggunakan skala Likert. Angket diberikan kepada reponden yaitu 10 orang guru sekolah dasar yang mewakili anak usia 6 sampai 9 tahun. Adapun hasil rekapitulasi dari jawaban responden disajikan pada tabel 10 .

Tabel 10. Hasil pengujian usability

\begin{tabular}{lccc}
\hline & Nilai & Jumlah & Jumlah Nilai \\
\hline SS & 5 & 76 & 380 \\
S & 4 & 206 & 824 \\
RG & 3 & 14 & 42 \\
TS & 2 & 4 & 8 \\
STS & 1 & 0 & 0 \\
& Nilai Total & & $\mathbf{1 2 5 4}$ \\
\hline
\end{tabular}

Nilai total yang didapatkan yaitu 1254, sedangkan nilai total maksimal didapatkan jika semua responden menjawab sangat setuju dengan nilai 5, sehingga dapat diperoleh nilai total maksimal 1500.Berdasarkan hasil yang didapatkan dari pengujian usability pada tabel 11, didapatkan hasil persentase sebagai berikut:

$$
\begin{aligned}
\text { Presentase } & =\frac{\text { Milai Total }}{\text { Milai Maksimal }} \times 100 \% \\
& =\frac{1254}{1500} \times 100 \% \\
& =83,6 \%
\end{aligned}
$$

Dari hasil perhitungan pada pengujian usability didapatkan persentase 83,6\% dan masuk klasifikasi sangat baik. Oleh karena itu, game edukasi “Adventure of Frunimal” telah memenuhi aspek usability. 
Berdasarkan hasil rekapitulasi keseluruhan jawaban responden terhadap kuesioner USE yang digunakan, didapatkan hasil rekapitulasi dari empat dimensi yang direkomendasikan dalam kuesioner USE yang disajikan pada tabel 11 .

Tabel 11. Hasil rekapitulasi dimensi dalam kuesioner USE

\begin{tabular}{lcccc}
\hline \multicolumn{1}{c}{ Dimensi } & Butir Soal & Jumlah Soal & $\begin{array}{c}\text { Jumlah Nilai } \\
\text { Yang Didapat }\end{array}$ & $\begin{array}{c}\text { Jumlah Nilai } \\
\text { Maksimal }\end{array}$ \\
\hline Usefulness & $1-8$ & 8 & 333 & 400 \\
Ease of Use & $9-19$ & 11 & 445 & 550 \\
Ease of & $20-23$ & 4 & 168 & 200 \\
Learning & & & & 350 \\
Satisfaction & $24-30$ & 7 & 308 & \\
\hline
\end{tabular}

Berdasarkan hasil yang didapatkan dari rekapitulasi dimensi-dimensi dalam kuesioner USE pada tabel 11, didapatkan hasil persentasi dari masing-masing dimensi sebagai berikut.

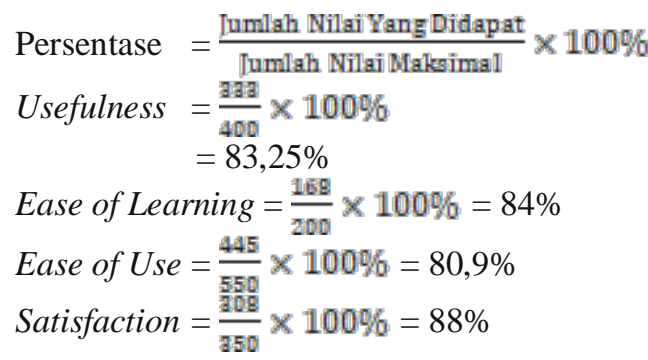

Dari hasil perhitungan masing-masing dimensi pada pengujian usability didapatkan persentase antara lain yaitu usefulness sebesar 83,25\% (masuk klasifikasi sangat baik), ease of use sebesar 80,9\% (masuk klasifikasi sangat baik), ease of learning sebesar 84\% (masuk klasifikasi sangat baik) dan satisfaction sebesar 88\% (masuk klasifikasi sangat baik).

\section{KESIMPULAN}

Berdasarkan hasil penelitian dan pembahasan maka dapat diambil kesimpulan sebagai berikut:

a) Game edukasi bahasa Inggris “Adventure of Frunimal” dapat dikembangkan dengan game engine Construct.

b) Proses pengembangan menggunakan metode pengembangan multimedia Luther yang terdiri dari enam tahap yaitu concept (konsep), design (desain), obtaining content material (pengumpulan materi), assembly (pembuatan), testing (pengujian), dan distribution (pendistribusian).

c) Pengujian dilakukan pada empat aspek antara lain aspek functional suitability yang menghasilkan presentase sukses sebesar 100\% (sudah memenuhi standar AQuA). Pada aspek performance efficiency, penggunaan CPU per 32 detik sebesar 6\% dan sudah memenuhi ambang batas aman yang ditetapkan oleh Little Eye yaitu dibawah 15\%, sedangkan penggunaan memory per 32 detik sebesar 199 MB serta tidak terjadi memory leak. Pada aspek compatibility yang dilakukan pada OS Android dari versi Ice Cream Sandwich sampai Marshmallow telah memenuhi aspek compatibility. Dan pada aspek usability secara keseluruhan didapatkan persentase sebesar 83,6\% sedangkan hasil persentasi dari masing-masing dimensi pada pengujian usability didapatkan persentase masing-masing antara lain yaitu usefulness 83,25\%, ease of use $80,9 \%$, ease of learning $84 \%$ dan satisfaction $88 \%$ (klasifikasi sangat baik).

\section{DAFTAR PUSTAKA}

[1] Ekawati, P.L., dan Falani, A.Z., 2015, Pemanfaatan Teknologi Game Untuk Pembelajaran Mengenal Ragam Budaya Indonesia Berbasis Android, Program Studi Sistem Komputer, Fakultas Ilmu Komputer, Universitas Narotama, Surabaya

[2] Agustina, C., dan Wahyudi, T., 2015, Aplikasi Game Pendidikan Berbasis Android Untuk Memperkenalkan Pakaian Adat Indonesia, Program Studi Manajemen Informatika, AMIK Bina Sarana Informatika Yogyakarta, Yogyakarta. 
[3] Hikmatyar, M., 2015, Analisis Pengembangan Game Edukasi “Indonesiaku” Sebagai Pengenalan Warisan Budaya Indonesia Untuk Anak Usia 12-15 Tahun, Program Studi Pendidikan Teknik Informatika, Fakultas Teknik, Universitas Negeri Yogyakarta, Yogyakarta.

[4] Sutopo, H., 2009, Pengembangan Evaluasi Pembelajaran Berbasis Multimedia Dengan Flash, PHP dan MYSQL, Universitas Persada Indonesia YAI, Jakarta.

[5] Arista, P., D., 2016, Pengembangan Brosur Interaktif “Aryappi” Berbasis Augmented Reality Sebagai Media Iklan SMK Yappi Wonosari, Program Studi Pendidikan Teknik Informatika, Fakultas Teknik, Universitas Negeri Yogyakarta, Yogyakarta. 